\title{
Characterization of Duplex Stainless Steel Weld Metals Obtained by Hybrid Plasma-Gas Metal Arc Welding
}

\author{
(Caracterização de Soldas de Aço Inoxidável Duplex Obtidas por Soldagem Híbrida MIG-Plasma)
}

\author{
Koray Yurtisik', Suha Tirkes ${ }^{1}$, Igor Dykhno², C. Hakan Gur ${ }^{3}$, Riza Gurbuz ${ }^{3}$ \\ 1Middle East Technical University, Welding Technology and Non-destructive Testing Research/Application Center, Ankara, Turkey, \\ yurtisik@metu.edu.tr,stirkes@metu.edu.tr \\ 2Plasma Laser Technologies NA, Inc., MI, United States of America, igor.dykhno@plasma-laser.com \\ 3Middle East Technical University, Department of Metallurgical and Materials Engineering, Ankara, Turkey, chgur@metu.edu.tr \\ rgurbuz@metu.edu.tr
}

\begin{abstract}
Despite its high efficiency, autogenous keyhole welding is not well-accepted for duplex stainless steels because it causes excessive ferrite in as-welded duplex microstructure, which leads to a degradation in toughness and corrosion properties of the material. Combining the deep penetration characteristics of plasma arc welding in keyhole mode and metal deposition capability of gas metal arc welding, hybrid plasma - gas metal arc welding process has considered for providing a proper duplex microstructure without compromising the welding efficiency. $11.1 \mathrm{~mm}$-thick standard duplex stainless steel plates were joined in a single-pass using this novel technique. Same plates were also subjected to conventional gas metal arc and plasma arc welding processes, providing benchmarks for the investigation of the weldability of the material. In the first place, the hybrid welding process enabled us to achieve less heat input compared to gas metal arc welding. Consequently, the precipitation of secondary phases, which are known to be detrimental to the toughness and corrosion resistance of duplex stainless steels, was significantly suppressed in both fusion and heat affected zones. Secondly, contrary to other keyhole techniques, proper cooling time and weld metal chemistry were achieved during the process, facilitating sufficient reconstructive transformation of austenite in the ferrite phase.
\end{abstract}

Key-words: Hybrid welding; Keyhole welding; Duplex stainless steel; Phase balance; Secondary phases.

Resumo: Apesar da alta eficiência da soldagem autógena utilizando a técnica de "keyhole", a mesma não é recomendada na soldagem de aços inoxidáveis duplex devido à redução tanto da tenacidade como da resistência à corrosão de tais aços. Combinando a característica de alta penetração da soldagem plasma no modo "keyhole" e a elevada capacidade de deposição do processo MIG, o processo hibrido MIG-plasma tem sido considerado promissor na obtenção de uma microestrutura ideal sem comprometer a eficiência da soldagem. Neste trabalho chapas de $11.1 \mathrm{~mm}$ de espessura foram unidas utilizando esta nova técnica. De forma comparativa, foram obtidas uniões utilizando os processos MIG e plasma convencionais. Inicialmente, foi constatado um menor aporte de calor pelo processo híbrido em relação ao processo MIG e como consequência a precipitação de fases secundárias, as quais são conhecidas por comprometer a tenacidade e resistência à corrosão, foram significativamente suprimidas tanto na solda como na zona termicamente afetada. Além disto, contrariamente a outras técnicas utilizando "keyhole" foram obtidas taxa de resfriamento adequada bem como homogeneidade química durante o processo permitindo a obtenção de uma suficiente transformação da austenita a partir da fase ferrítica.

Palavras-chave: Soldagem hibrida; Soldagem “keyhole”; Aço inoxidável; Equilibrio de fases; Fases secundarias.

\section{Introduction}

Duplex stainless steels (DSS) have a significant competitive value among stainless steels because of its high strength and the lower content of Ni. Moreover, due to its high pitting corrosion resistance, design engineers prefer to utilize DSS rather than austenitic stainless steels as enclosing and

Recebido em 11/12/2012. Texto final em 05/04/2013. constructive assemblies where especially chloride attack is a significant problem. The advantageous characteristics of DSS are guaranteed by a balanced austenite $(\gamma) /$ delta-ferrite $(\delta)$ distribution with minimum possible amount of secondary phases in the microstructure. Any thermal treatment above $300^{\circ} \mathrm{C}$, such as fusion welding, may deteriorate the optimum microstructure of DSS [1 - 3].

The metallurgy of the as-welded DSS is principally determined by the weld metal composition and the cooling rate. Heat input, preheating and inter-pass temperatures during welding operations are major factors that affect the cooling rate. While fast cooling rates retain more of the ferrite and lead to a 
higher probability of precipitation of nitrides [4, 5], slow cooling rates and prolonged welding durations increase the possibility of spinodal decomposition of Cr-rich-ferrite $\left(\alpha^{1}\right)$, namely $475^{\circ} \mathrm{C}$ embrittlement, and precipitation of intermetallics, such as Sigma $(\sigma)$ and Chi $(\chi)[6]$. Therefore heat input has to be in tight upper and lower limits and inter-pass temperatures are kept relatively low $\left(180-200^{\circ} \mathrm{C}\right)$ during conventional multi-pass fusion welding in order to obtain moderate cooling rates $[1,7]$. Controlling such low-tolerance welding parameters brings extra engineering and fabrication man-hours during conventional multi-pass welding processes.

As long as the solidified microstructure is controlled, welding of DSS in a single pass would provide both welding economy and consistency in metallurgical and mechanical quality. Singlepass weldments of DSS can be obtained by plasma arc welding (PAW), Laser beam welding (LBW), hybrid Laser arc welding (HLAW) and electron beam welding (EBW) in keyhole mode. However, these welding techniques are applicable to joints that have very narrow gap or no gap, therefore it is not possible to introduce proper amount of filler metal, which has excess $\mathrm{Ni}$, to the weld metal to obtain enough $\gamma$ in $\delta$ matrix. Beside their very low heat inputs $[8,9]$, autogenous or partly-autogenous keyhole welding may lead to an excess $\delta$-ferrite forming in aswelded DSS that leads to deterioration of the toughness and the corrosion properties of the material $[10,11]$. Therefore, PAW, LBW, HLAW and EBW of DSS normally requires post-weld treatments, like solutionizing, in order to obtain a weld metal microstructure which has a proper phase balance and is free from secondary phases [12]. Either addition of little amount of nickel powder [13] or assist-charging of nitrogen into the fusion zone during such welding processes have been observed to restore the correct $\gamma$ to $\delta$ ratio [14]. However, such interventions again increase the cost and complexity of welding processes by adding new parameters to control.

A recently developed hybrid plasma-gas metal arc welding (HPAW) process, which has been patented with the name
SuperMIG, takes advantage of combining the deep penetration characteristics of PAW with the filler metal deposition capability of gas metal arc welding (GMAW). The technique has been successfully applied to non-alloyed steels and weldability features were previously published [15]. The present work addresses the microstructural and mechanical stability of standard duplex stainless steel (grade 2205) weldments obtained by this hybrid welding technique. In order to provide a reference point for metallurgical and mechanical characterization data, the same investigation methodology was applied on DSS plated welded either only by GMAW or PAW methods. Phase transformation and precipitation processes were evaluated with respect to weld heat input and cooling rate data recorded during welding performances. Hardness and impact toughness properties of as-welded material were discussed in terms of the microstructural characteristics of the fusion zone (FZ) and the heat affected zone (HAZ) of weldments.

\section{Materials and Methods}

\subsection{Materials and Welding Procedures}

An $11.1 \mathrm{~mm}$-thick duplex stainless steel plate, conforming to ASTM A240 S32205, were sectioned and beveled for butt welding operations. PAW was applied on square-groove butt joint and the root gap was $0.5 \mathrm{~mm}$ in order to stabilize the operation, which requires equilibrium between the pressures of the orifice gas and the metal vapor through the keyhole. Conventional bevel angle, root face and gap sizes were introduced to V-grooved butt joint for the GMAW performance. A joint design was developed specifically for HPAW considering convection and dilution processes. Beveling details for all three techniques are given in Figure 1.

Plates were clamped to a platform at the flat $(1 \mathrm{G})$ position and the movement of an industrial robot drove torches. Unlike GMAW and PAW, two different arcs are formed simultaneously

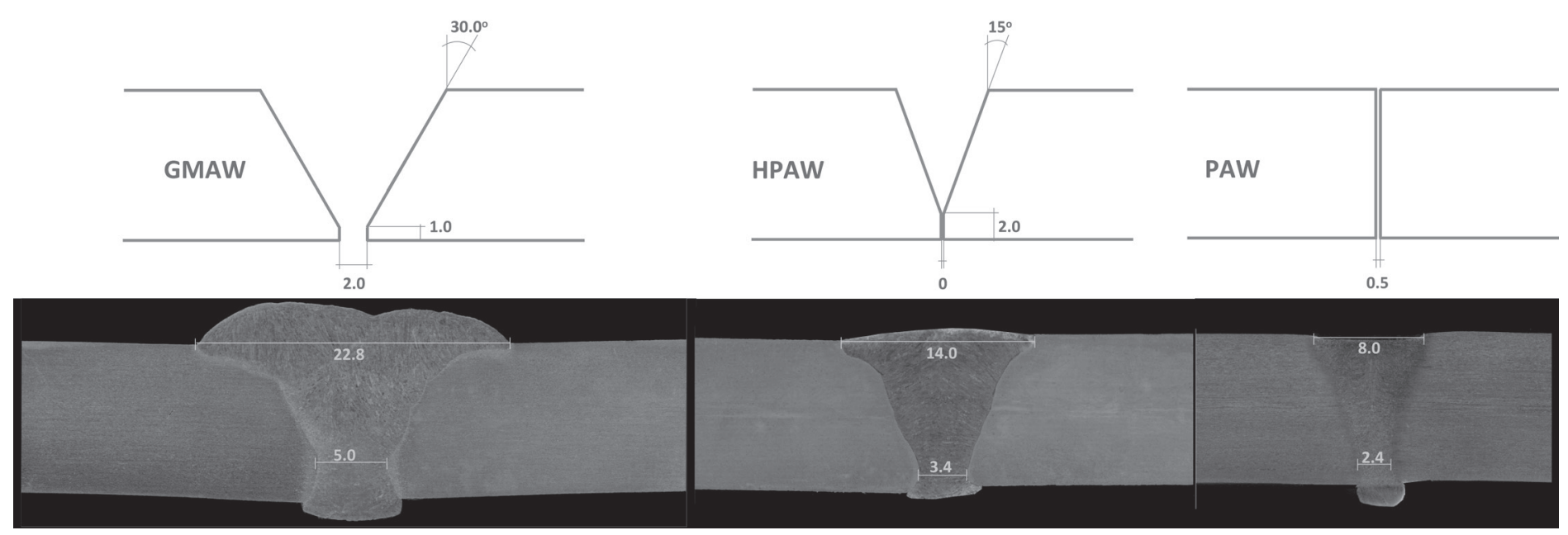

Figure 1. Edge preparations for butt welding of $11.1 \mathrm{~mm}$-thick plates and corresponding weld macro sections. 
in HPAW; namely a straight polarity direct current between the work piece and tungsten electrode and a reversed polarity direct current between the welding wire electrode and the work piece. Basic working principle of the HPAW technique was schematized in Figure 2. Welding parameters are detailed in Table 2.

1. Work piece

2. Plasma jet

3. Metal vapor column and surrounding molten metal

4. Orifice nozzle and Tungsten electrode

5. Consumable wire electrode

6. Wire-arc current direction

7. Plasma-arc current direction

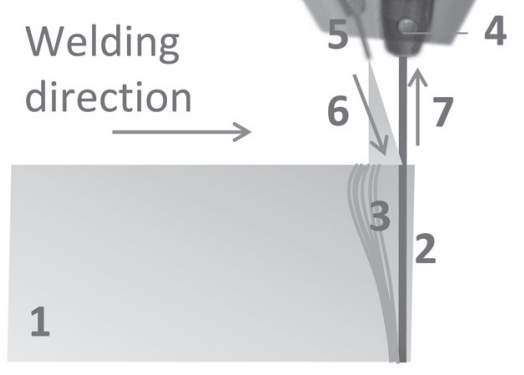

Figure 2. A basic schema presenting the working principle of a hybrid plasma arc welding called SuperMIG.

SFA/AWS 5.9 ER2209 DSS wire electrode was applied during GMA and HPA welding performances. The chemical constituent of the base metal (BM) and filler metal were represented in Table 1. Argon- $2 \% \mathrm{O}_{2}$ mixture of gas was applied for shielding of the solidifying weld metal and HAZ during GMAW and keyhole welding (HPAW and PAW) processes and with the flow rates of 14 and 21 liters per minute, respectively. High purity argon was used as orifice gas during HPAW and PAW performances with the flow rate of 4.5 liters per minute and the orifice diameter was $3.2 \mathrm{~mm}$.
Assembling the plates in a way that root gaps were kept closer than the diameter of the arc column enabled us to obtain stable keyholes during PAW and HPAW. Consequently the plasma arc could impinge on the joint, melt the material and create the weld pool. In the keyhole technique, since the molten pool is prevented from spilling by its surface tension, normally no backing is required for materials having thicknesses up to 6 $\mathrm{mm}$. Ceramic backing was utilized to support the weld pool not only during the root pass of GMAW but also single-pass keyhole welding of the plates that were $11 \mathrm{~mm}$-thick.

Cooling times were recorded between 1300 and $200^{\circ} \mathrm{C}$ by plunging Type $\mathrm{K}$ chromel thermocouples with ceramics sheath into the weld pool and switching off the arc at the same time. The diameter of thermocouple wires were $1.0 \mathrm{~mm}$. A data acquisition system (SCXI 1112-8 channel thermocouple amplifier with in SCXI 1000 chassis) was used to record temperature versus time data at the sampling rate of $10 \mathrm{~Hz}$. Cooling rates were calculated and presented in Table 2.

After completing the welding processes, integrity of weldments was confirmed using radiographic examination. Residual stress distributions on each weldment were nondestructively determined by Magnetic Barkhausen noise (MBN) technique using Stress-Tech Rollscan- $\mu$ scan 500-2 and the probe 4316. MBN amplitudes were calibrated during a uniaxial tensile testing by fixing the MBN probe on the specimen. The details of the calibration and measurement procedures can be found in literature [16].

\subsection{Metallography and Quantitative Analysis}

A Fisher Ferritoscope was employed to measure the fraction of ferromagnetic ( $\delta$-ferrite) phases in as-welded specimens. Amounts of $\delta$ and $\gamma$ constituents were qualitatively estimated using X-ray diffraction (XRD) studies. Diffractograms were obtained for powder samples extracted from fusion zone of all weldments. $\mathrm{CuK} \alpha$ radiation was utilized at $2 \theta$ range from $20^{\circ}$ to $70^{\circ}$ with the scanning rate of $0.5^{\circ} \mathrm{min}^{-1}$.

The pieces joined using three different welding methods were sectioned transverse to the weld direction for microstructural characterization. Grinding with various grades of $\mathrm{SiC}$ papers was followed by polishing using Alumina colloidal. The samples were etched with $40 \% \mathrm{NaOH}$ electrolytic ( $-4 \mathrm{~V}, 20$ seconds) and Beraha II reagents to enhance the contrast between $\delta$ and $\gamma$ phases. The specimens were examined using light optical microscopy. Ferritescope measurements and XRD analyses were supported by quantitative metallography, where a pixelcount software was exploited.

Table 1. Major alloying elements in weight fractions in the base metal (S32205) and the filler metal (ER 2209).

\begin{tabular}{c|c|c|c|c|c|c|c|c|c} 
wt \% & $\mathbf{C}$ & $\mathbf{S i}$ & $\mathbf{M n}$ & $\mathbf{P}$ & $\mathbf{S}$ & $\mathbf{C r}$ & $\mathbf{N i}$ & $\mathbf{M o}$ & $\mathbf{N}$ \\
\hline S32205 & 0.015 & 0.39 & 1.6 & 0.023 & 0.001 & 22.8 & 4.8 & 2.6 & 0.19 \\
\hline ER2209 & 0.010 & 0.45 & 1.5 & 0.020 & $<0.01$ & 22.9 & 8.7 & 3.1 & 0.17
\end{tabular}


Table 2. Welding parameters utilized during gas metal arc (GMAW), hybrid plasma arc (HPAW) and plasma arc welding (PAW) performances.

\begin{tabular}{|c|c|c|c|c|}
\hline & & GMAW & HPAW & PAW \\
\hline Wire feeding speed, WFS & $\mathrm{m} \mathrm{min}^{-1}$ & $8.9-10.1$ & 17.8 & \\
\hline Wire-arc current & $\mathrm{A}$ & $210-230$ & 320 & $N / A$ \\
\hline Wire-arc potential & $\mathrm{V}$ & $22-24$ & 27 & \\
\hline Plasma-arc current & A & \multirow{2}{*}{$N / A$} & 190 & 190 \\
\hline Plasma-arc potential & $\mathrm{V}$ & & 15 & 15 \\
\hline Linear welding speed, LWS & $\mathrm{cm} \mathrm{min}^{-1}$ & $35-40$ & 50 & 20 \\
\hline Heat input, per pass & $\mathrm{kJ} \mathrm{mm}^{-1}$ & $0.48-0.70$ & \multirow{2}{*}{1.09} & \multirow{2}{*}{0.51} \\
\hline Heat input, total & $\mathrm{kJ} \mathrm{mm}^{-1}$ & 2.38 & & \\
\hline Cooling rate & ${ }^{\circ} \mathrm{C} \mathrm{s}^{-1}$ & $108.3-75.7$ & 27.1 & 33.1 \\
\hline
\end{tabular}

The specimens were examined using light optical microscopy and scanning electron microscopy (SEM). Cr, Mo and Ni were analyzed using energy dispersive X-ray spectroscopy (EDX) in $\gamma$ and $\delta$ grains and around precipitates of secondary phases.

\subsection{Mechanical Testing}

Simple-beam Charpy impact test specimens were machined to $55 \mathrm{~mm}$ in length, $10 \mathrm{~mm}$ in depth and width with their 2-mm V-notches (type A) transverse to the weld direction, perpendicular to the plate surface and centered at the weld metal and fusion lines. Specimens were then subjected to Charpy impact toughness tests at $-50^{\circ} \mathrm{C}$ in accordance with ASTM E23. Micro-hardness survey using a Vickers indenter at a load of 9.8 $\mathrm{N}$ (HV1) was carried out on transverse planes to the welding direction; the spacing between indentations was $0.5 \mathrm{~mm}$. A detailed micro-hardness investigation was carried out on the $\delta$ grains in HAZ of all weldments at a load of $0.49 \mathrm{~N}$ (HV0.05).

\section{Results and Discussion}

\subsection{Conduction versus Keyhole Mode of Welding}

The $11.1 \mathrm{~mm}$-thick DSS plates were joined in 4 passes of GMAW and in a single pass of HPAW and PAW (Figure 1). The ratio of penetration of weld bead to its width (aspect ratio) was calculated as 0.6 (average of passes), 1.5 and 2.5 for GMA, HPA and PA welds, respectively. As a conventional arc welding process, GMAW operates in conduction (melt-in) mode. During the conduction mode of welding, the arc tends to diverge through the spacing between the tip of the electrode and the work piece. Therefore the effective radius of energy density distribution is high and consequently the fusion effect is limited to surface and sub-surface of the work piece. Whereas, in PAW and HPAW, the arc in between the tungsten electrode and the work piece is constricted due to the converging action of the orifice gas nozzle. The plasma arc is technically columnar due to the constriction provided by the nozzle. This constricted arc leads to high specific point energies at the surface of the work piece, which yields a vapor column (keyhole) through the thickness of the work piece. The heat, which is produced by both the anode spot on the work piece and the plasma stream, can be deposited and transferred below its surface during keyhole mode of welding. The keyhole turns the gradient of surface tension of the weld pool from negative to positive that is normally positive to negative in melt-in (conduction) mode of welding [17, 18], therefore the mode of fusion welding is a principle determinant for the convection in weld pool and penetration as well.

Keyhole based welding techniques (PAW and HPAW) provided significantly higher efficiency parameters as compared to that of the melt-in technique, GMAW. Deep penetration capability of the keyhole welding provided the possibility to work with narrower gaps and complete the joining process in a single run without an integrity problem. In the first place, reduced bevel angle for HPAW required less filler wire than the one introduced to the conventional V-groove. Pursuing this further, single-pass welding provided considerably less arc times and no inter-pass pauses, which are beneficial for the economy of welding (Figure 3).

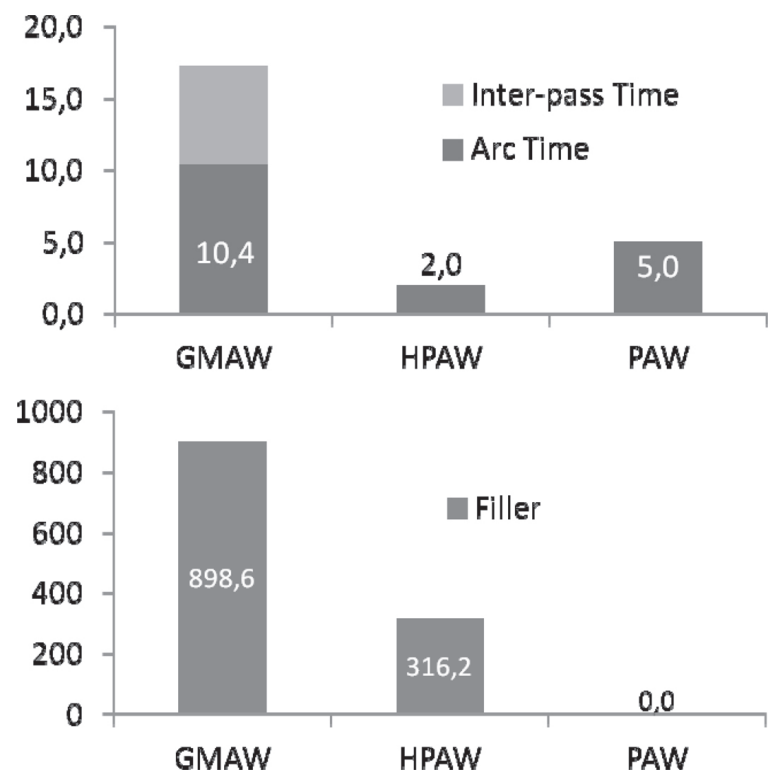

Figure 3. A comparison for welding durations and filler consumptions of all welding processes worked. 


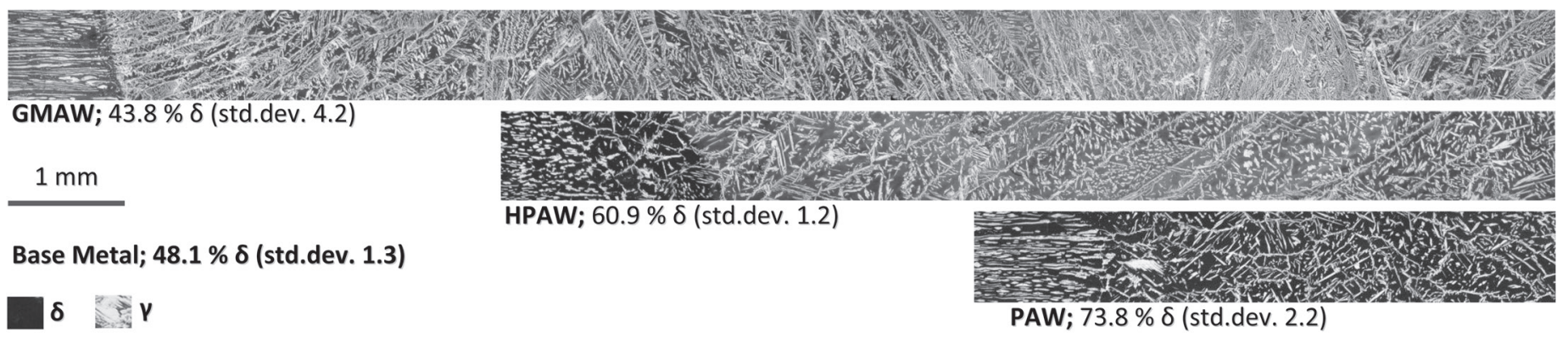

Figure 4. Fusion and heat affected zones of GMA, PA and HPA weldments and unaffected base material under low magnification. $\delta$-ferrite contents in fusion zones of weldments are also indicated below the microstructures.

\subsection{Solidification Structure}

Equiaxed grains at the weld center and columnar grains at sides typically formed the weld metal structure of PA and HPA weldments (Figure 4). Equiaxed dendritic structure in the middle of fusion zone indicates the relatively higher level of constitutional supercooling during the solidification. Equiaxed structure was more clearly observed in the center line of the fusion zone of PA weldment, where solidification rates are highest.

Almost only columnar dendrites were observed in the fusion zone of GMA weldment. Columnar dendrites formed nearly perpendicular to the fusion line in all weldments. This indicates the maximum thermal gradient and so the characteristic of the heat flow, which is 2-dimensional in high-aspect-ratio beads obtained via keyhole formation and 3-dimensional in lowaspect-ratio beads in the GMA weldment.

\subsection{Heat Input and Cooling Rate}

The microstructure of as-welded DSS is caused by both phase transformations during solidification and consequent solid state transformations, which are mainly controlled by the composition of the material and the cooling rate. Cooling rate is determined by the heat input by the welding process and heat transfer conditions in the material.

During the calculations, basic heat input definition was utilized;

$$
H=\frac{P(k V A)}{L W S\left(m m \sec ^{-1}\right)} \eta
$$

where $\mathrm{H}\left(\mathrm{kJ} \mathrm{mm}^{-1}\right)$ is heat input, $\mathrm{P}$ is welding power, LWS is linear welding speed, and $\eta$ is arc efficiency factor (thermal transfer efficiency - the ratio of the heat absorbed by the work piece to the welding energy) for a specific welding method. Arc efficiency factor is assumed 0.85 for the filler wire arc and 0.60 for the constricted plasma arc $[19,20]$.

Calculated cooling rates between 1200 and $500^{\circ} \mathrm{C}$ and heat input values are given in Figure 2. Taking the preheat temperature constant; cooling rates were inversely proportional to the heat and the size of the bead provided by the welding process. For typical plate dimensions and preheat temperature $\left(20^{\circ} \mathrm{C}\right)$, cooling rate of GMAW single-pass was higher than ones for the single-pass of HPAW and PAW. Cooling rate of following GMAW passes decreased due to the inter-pass temperature of $180^{\circ} \mathrm{C}$, but it was still lower than that of HPAW and PAW passes.

Relatively higher cooling rate during GMAW can be explained by both low heat input per each pass and 3-dimensional heat dissipation. However, the total amount of heat introduced during GMAW process was higher than that introduced during welding process of $11.1 \mathrm{~mm}$-thick DSS plates using PAW and HPAW. This not only leads to a metallurgically less stable GMA weldment, but also relatively higher residual stress fields on the weldment (Figure 9).

\subsection{Microstructure}

DSS solidifies first as columnar and equiaxed $\delta$ grains in the fusion zone. During continuous cooling, there is not enough time for the $\gamma$ to precipitate until the temperature has decreased to about $1100^{\circ} \mathrm{C}$, when a sufficient amount of nuclei has been formed at columnar $\delta$ grain boundaries [21]. Below that temperature, $\gamma$ primarily precipitates as allotriomorphic form by a considerable diffusion rate of $\gamma$ former elements like $\mathrm{Ni}$ and $\mathrm{N}$. Diffusion significantly slows down in equilibrium conditions at about $600^{\circ} \mathrm{C}$. After the reconstructive transformation of $\gamma$ from $\delta$, displacive transformation process starts to take place below $600^{\circ} \mathrm{C}$. During this transformation process, $\gamma$ precipitates as Widmanstätten plates toward the center line of columnar grains. Kinetics of this process is determined by composition gradients in $\delta$ grains rather than diffusion of austenite formers, such as $\mathrm{Ni}$ and N. Since both allotriomorphic and Widmanstätten precipitates form during solidification of weld beads, they are called as primary austenite $\left(\gamma_{1}\right)$.

Results of quantitative metallography studies and Ferritescope measurements are represented in Figure 4. Autogenous PAW yielded a fusion and a heat affected zone, which contented excessive $\delta$. Ability to use filler metal with excess Ni promoted the formation of $\gamma_{1}$ in FZ under moderate cooling condition of HPAW and even under rapid cooling condition of GMAW. The content of $\delta$ in the FZ is principally determined by both the chemical composition and the cooling 


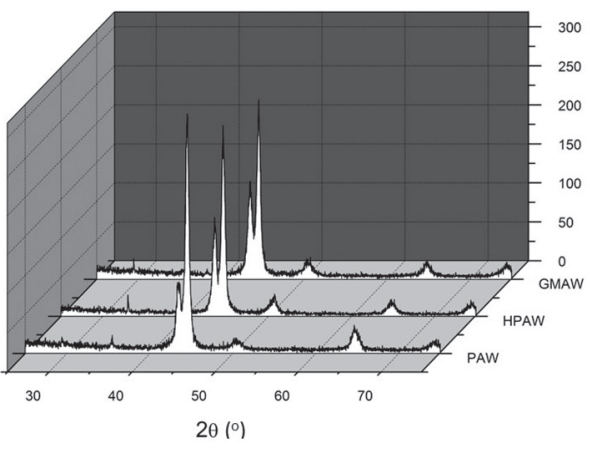

a

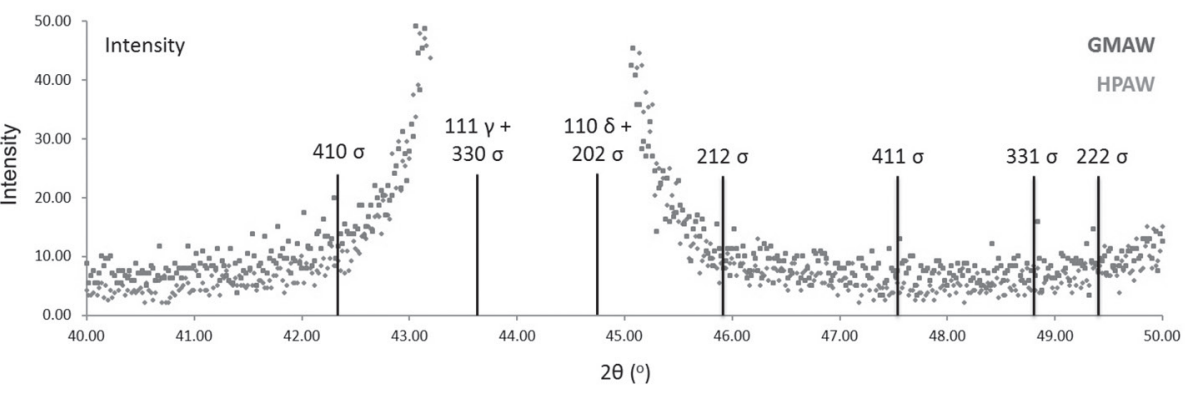

b

Figure 5. X-ray diffraction patterns obtained from powder samples of as-welded specimens; (a) $\delta$ and $\gamma$ peaks, (b) locations of $\sigma$-phase peaks and high-resolution diffractograms from GMA and HPA weldments.
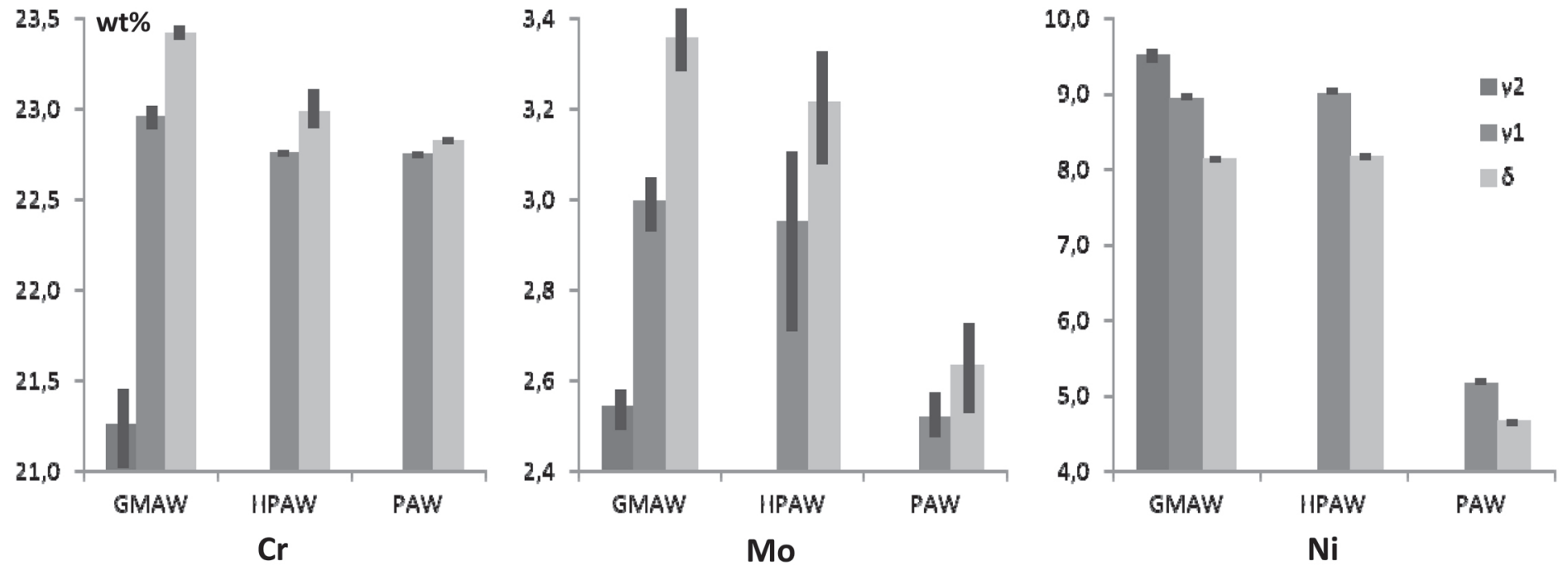

Figure 6. Graphical representations of solute redistribution in fusion zones of weldments.

rate. Despite varying cooling rates, HPA and GMA welds had comparable amounts of $\gamma_{1}$. Moreover, cooling rates during HPAW and PAW were comparable but volume fractions of the phases in the fusion zones were substantially different. Therefore it can be interpreted as that the chemical composition of the weld metal is the dominating factor on the phase fractions rather than the cooling rates. Intensities of $\gamma$ and $\delta$ peaks in diffractograms obtained from powder samples of the welds conformed to the metallographic observations and Ferritescope measurements. $\delta$ peaks had comparable intensities for GMAW and HPAW, whereas they had relatively higher intensities for PAW (Figure 5 a).

$\delta$ and $\gamma$ grains in fusion zones of all weldments were analyzed using EDX to examine the solute distribution in aswelded structure. High-cooling-rate caused suppression of solute redistribution in FZ and partially melted zone (PMZ) of GMA weldment [22], where Cr-rich precipitates were observed either in $\delta$ grains or at $\delta / \delta$ or $\delta / \gamma$ grain boundaries (Figure 7). Nilsson and Wilson [2] and Kokawa et al. [23] characterized these precipitates as $\mathrm{Cr}_{2} \mathrm{~N}$ and reported that the hydrogeninduced cracking susceptibility increased as the density of these precipitates increased in the material. Despite its lower cooling rate, $\mathrm{Cr}_{2} \mathrm{~N}$ precipitates observed also in PA weldments, probably because autogenous welding caused insufficient austenite phase that could solubilize the entire available $\mathrm{N}$.

Secondary phase formation is attributed to the repeating thermal cycles during multi-pass welding process. The temperature of a former weld pass increases above $600^{\circ} \mathrm{C}$ with the following passes, and this promotes solute redistribution and formation of secondary phases, such as secondary austenite $\left(\gamma_{2}\right)$ and intermetallic precipitates.

The $\gamma_{2}$ is transformed from $\delta$ via a martensitic shear process during repeating thermal cycles. Chemical compositions and preferred orientations of $\gamma$ and $\gamma_{2}$ are different and $\gamma_{2}$ had lower concentrations of $\mathrm{Cr}, \mathrm{Mo}$, and $\mathrm{N}$ than the $\gamma$ [23]. EDS analyses in $\gamma_{2}$ are consistent with literature data (Figure 6). $\gamma_{2}$ precipitates are expected to be more susceptible to pitting attack than $\gamma$. Acicular $\gamma_{2}$ formation could not be detected in single-pass HPA and PA weld metals, and outer surface of root and cap passes of GMA weld metal.

Intermetallic precipitates were detected on $\delta / \delta$ and $\delta / \gamma$ grain boundaries in HAZ of GMA weldment during metallographic investigations. However, intermetallic precipitation was observed to be significantly suppressed in HAZ of HPA and 


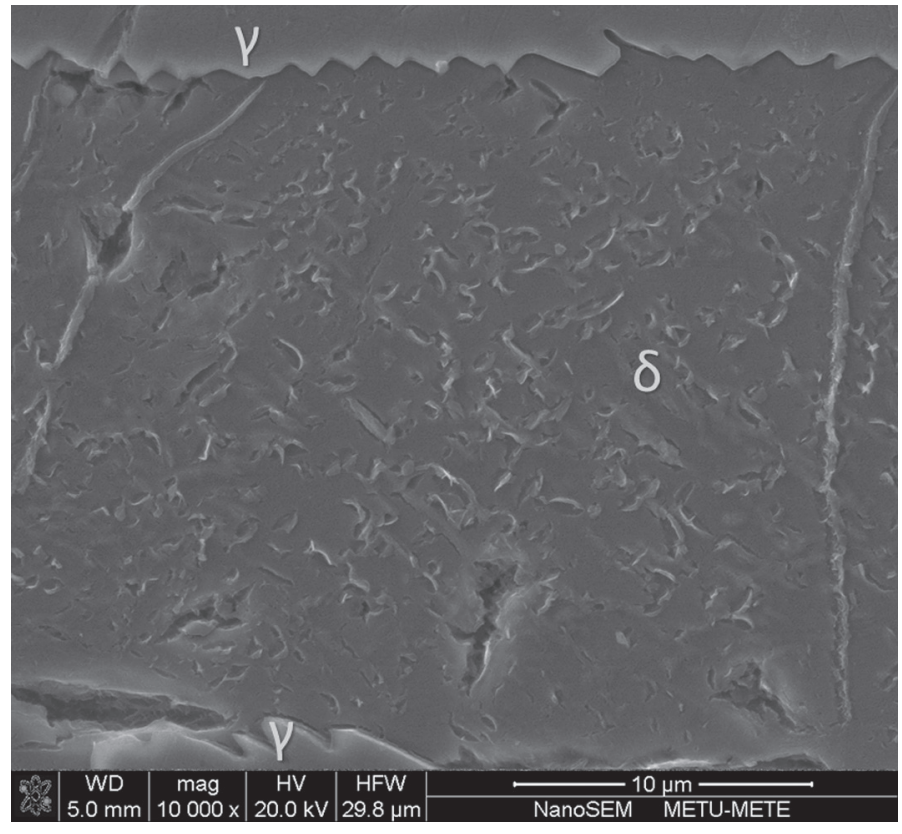

(a)

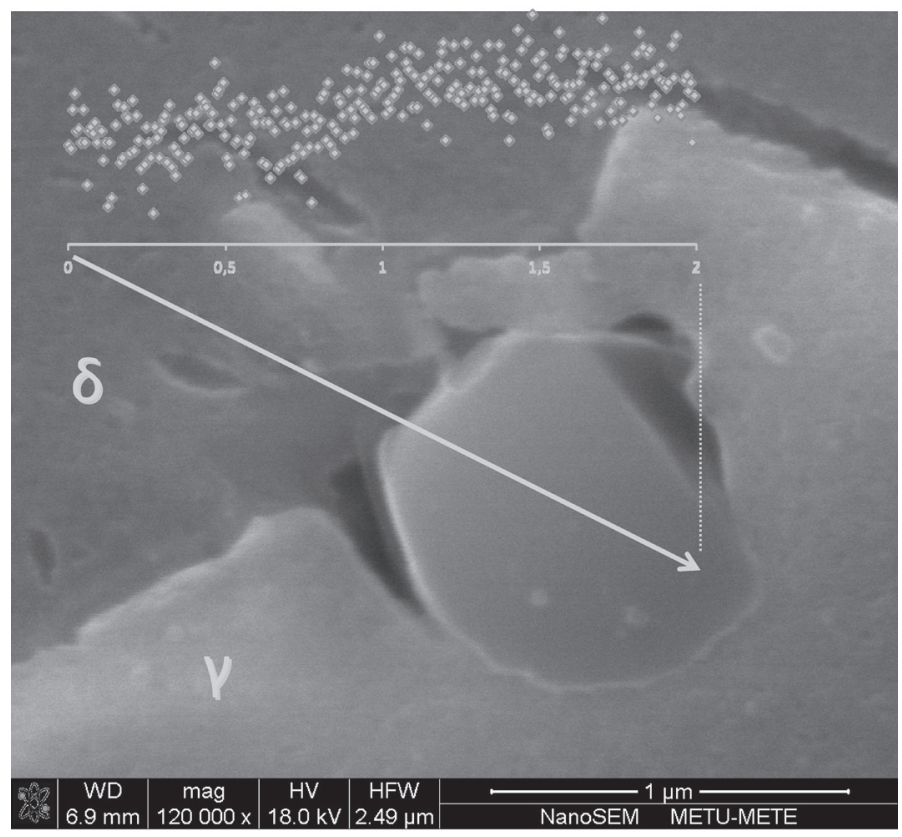

(c)

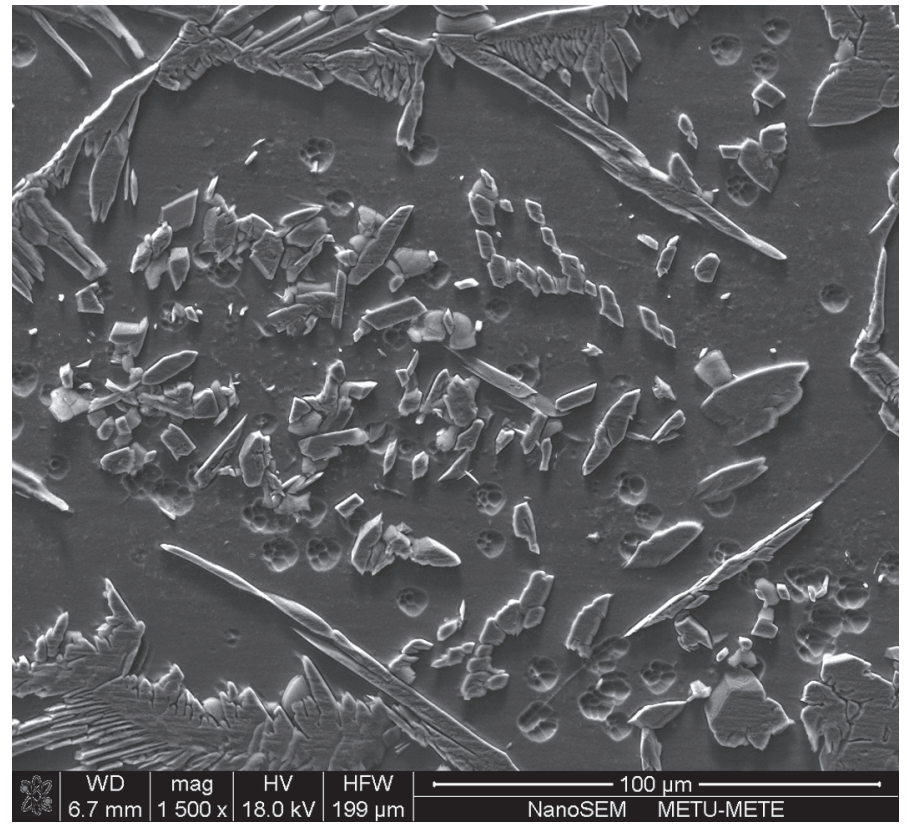

(b)

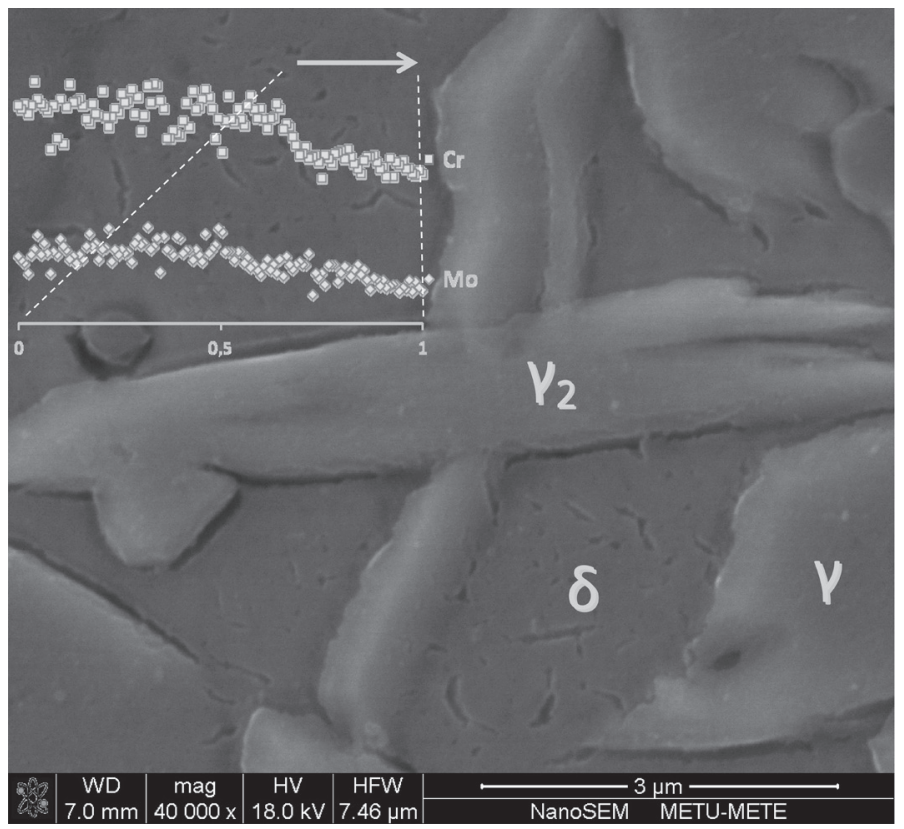

(d)

Figure 7. GMA and PA weld metal microstructures revealed by the Beraha etchant.

(a) $\mathrm{Cr}_{2} \mathrm{~N}$ precipitates in $\delta$ grains in $\mathrm{HAZ}$ of GMA.

(b) $\mathrm{Cr}_{2} \mathrm{~N}$ provides a preferred location for $\gamma_{2}$ precipitation.

(c) The advancing $\gamma$ phase boundary is pinned by a Cr-rich precipitate in GMA weld metal.

(d) Intragranular $\gamma_{2}$ precipitates in acicular form in GMA weld metal. EDS analysis of $\gamma_{2}$ has shown that concentrations of $\mathrm{Cr}$ and Mo were significantly low, which may lead sensitization.

PA weldments. Like $\gamma_{2}$ precipitates, it was analyzed that the formation of intermetallic phases also resulted in $\mathrm{Cr}$ and $\mathrm{Mo}$ depletion in the neighborhood of them (Figure 8). Negative effects of these intermetallic phases on toughness and corrosion properties of DSS have been reported [6]. 


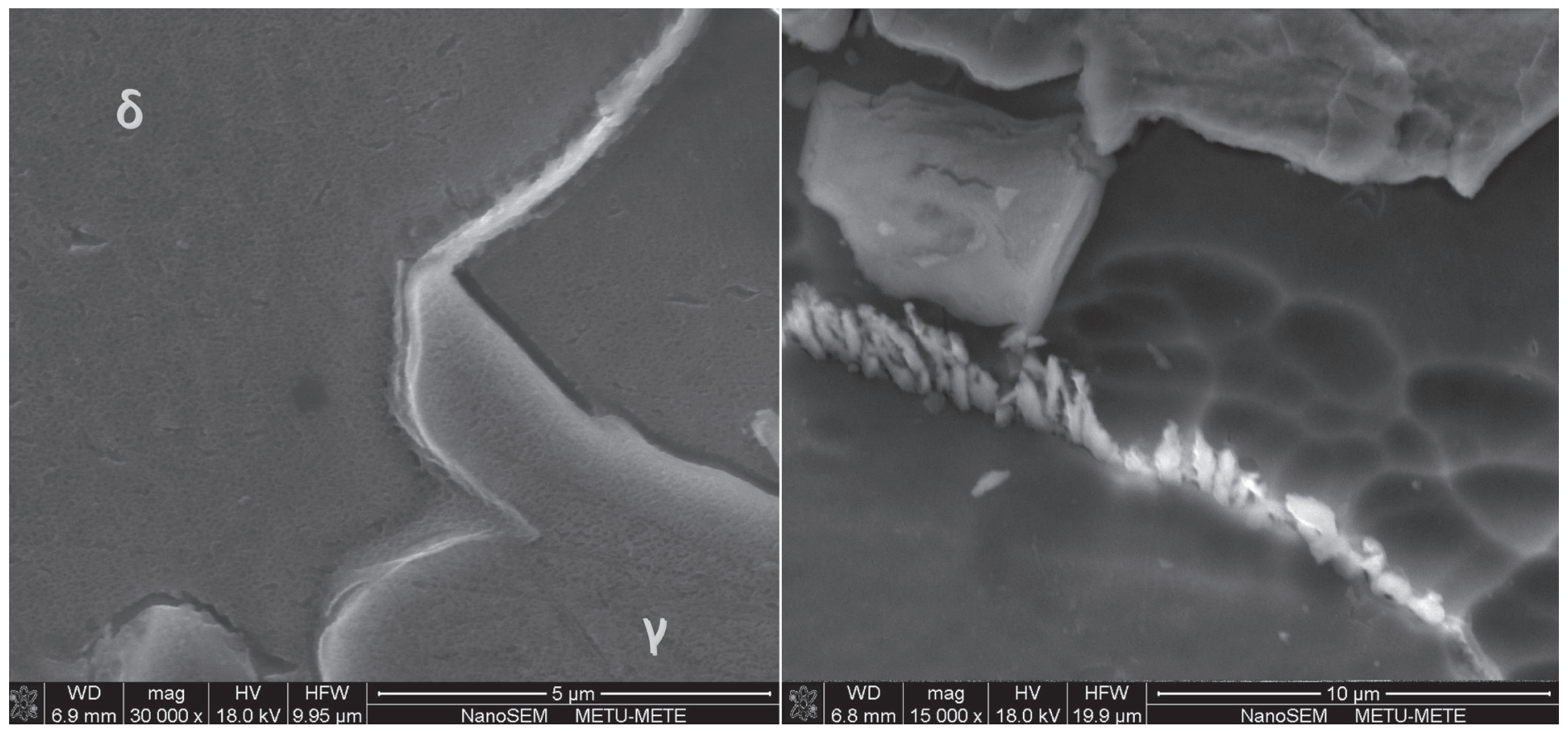

Figure 8. Intermetallic precipitations formed in $\delta / \delta$ and $\delta / \gamma$ grain boundaries in the HAZ of the GMA weldment.

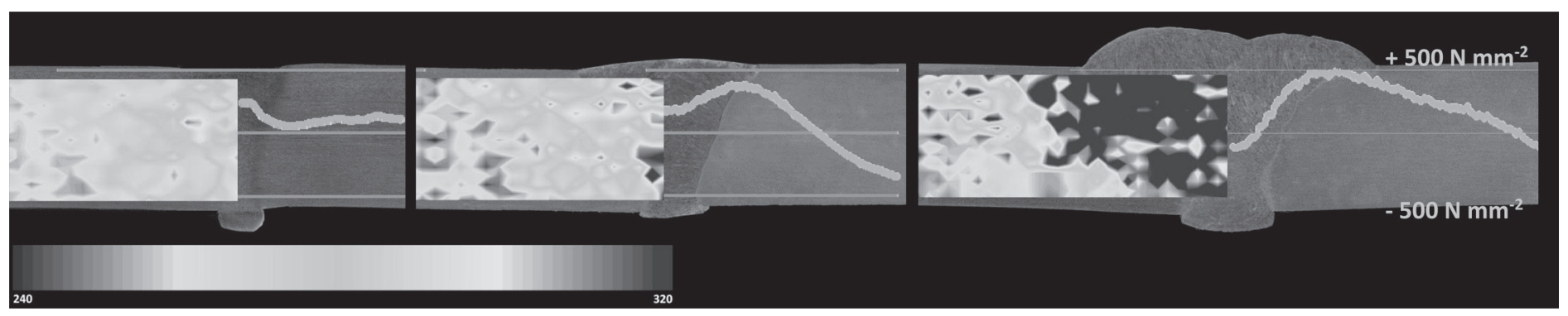

Figure 9. Hardness maps and residual stress profiles on macro sections of the weldments. Maximum hardness values and broadest HAZ were recorded for the weldment obtained by GMAW.

\subsection{Hardness and Impact Toughness}

Residual stresses measured on weldments by Magnetic Barkhausen Noise Analysis are represented in Figure 9. All three as-welded specimens had tensile stress fields at HAZ and the fusion line, whereas they presented near-zero or compressive stress distribution with distance from the weld. PAW provided the lowest stress magnitudes at both the fusion and the heat affected zones. The residual stresses are narrow for the autogenous PAW and broader for HPAW and GMAW. The maximum residual stress, which was detected in the fusion line of the GMA weldment, was nearly the same as the yield stress of the base material. The GMAW process had the highest peak probably due to the harder microstructure. Residual stress field widened with the greater heat input, which was maximum for GMAW.

Nilsson et al. [24] observed that the hardness was constant until $10 \%$ volume of secondary phases and started to increase above that volumetric fraction. It was detected by the microhardness examination that, relatively higher hardness values on HAZ of the GMA weldment were mainly due to the higher hardness values obtained at $\delta$ grains, where secondary phases usually prefer to precipitate. The average hardness in $\delta$ grains in the HAZ of HPA and GMA weldments were recorded as 318 and 384 HV0.01 respectively. On one hand, hard and brittle intermetallic phases, which precipitated more on the HAZ

Table 3. Charpy impact toughness energies $\left(\right.$ at $\left.-50^{\circ} \mathrm{C}\right)$ in Joules with maximum deviations. The charpy specimens were machined to 10x10x55 ( $\left.\mathrm{mm}^{3}\right)$ with their $2 \mathrm{~mm}$ V-notches at fusion zones, FZ, and fusion lines, FL, of weldments.

\begin{tabular}{|c|c|c|c|c|c|c|c|}
\hline & \multirow{2}{*}{ BM } & \multicolumn{3}{|c|}{ FZ } & \multicolumn{3}{|c|}{ FL } \\
\cline { 3 - 8 } & & $\boldsymbol{G M A W}$ & HPAW & PAW & GMAW & HPAW & PAW \\
\hline Impact Energy & $240.1,6.6$ & $92.3,4.4$ & $107.7,9.6$ & $23.6,2.7$ & $71.7,7.1$ & $148.7,6.9$ & $61.4,6.5$ \\
\hline
\end{tabular}



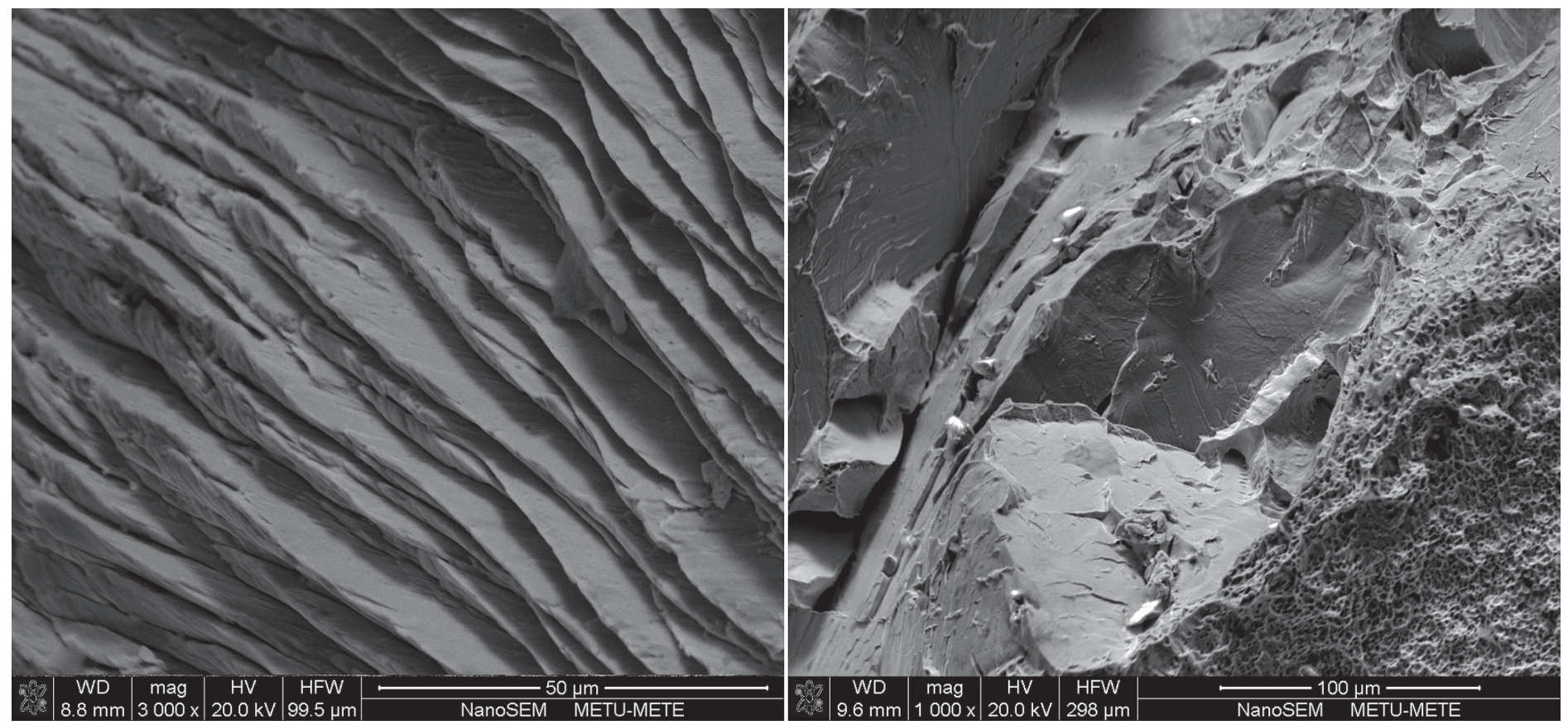

Figure 10. Fracture surfaces from the HAZ of GMA weldment (left) and the FZ of PA weldment (right) after Charpy impact toughness testing.

of GMAW than the HAZ of HPAW and PAW, could provide a reasonable explanation for relatively high hardness values on the fusion line and HAZ of GMAW. On the other hand, intermetallic precipitates cannot be the only explanation because impact toughness energies of GMAW specimens were still above the ductility limit (Table 3 ) and, despite the difference in XRD patterns of HPAW and GMAW (Figure $5 \mathrm{~b}$ ), the presence of intermetallic phases could not be clearly confirmed by XRD probably due to low volumetric fractions of them. Comparable residual stress magnitudes in HPA and GMA weldments support the argument that not only secondary phases, but also smaller grain size and strain hardening are determinants for the high hardness of GMAW.

Impact toughness energies obtained from the specimens, in which V-notches were centered at the weld metal and fusion lines of PA, HPA and GMA weldments were represented on Table 3. PAW yielded toughness energies lower than the ductility limit because of very high $\delta$ content in the microstructure. Relatively lower energies for fusion line of GMA weldment then the ones for HPA weldment would be attributed to the precipitation of brittle intermetallics. Calliari et al. [25] obtained a correlation between the volume fraction of secondary phases and impact toughness. They commented the main drop in toughness was due to the early stages of precipitation when the only phase detected was $\chi$-phase and $\sigma$-phase was still virtually absent. Cleavage areas on the fracture surfaces of V-notched charpy specimens corresponding to $\delta$ grains in HAZ of the weldments can also be associated to the embrittlement caused by intermetallic phases (Figure 10).

\section{Conclusion}

Weldability of $22 \mathrm{Cr}-5 \mathrm{Ni}$ DSS was investigated utilizing a non-conventional welding process, HPAW. The basic principle of this process is employing GMAW and PAW processes simultaneously and in the same torch. Observations on the weldment obtained by this hybrid welding technique were compared with the ones on weldments of conventional GMAW and PAW methods.

Conventional GMAW is a well proven welding method and aswelded DSS produced by this method is available for service as long as the heat input and pre-heat temperatures are precisely controlled. Whereas in PAW applications, since the ferrite density in DSS microstructures is above the threshold levels, the proper phase balance can only be obtained by solution treatment following welding. The two features, namely $40 \%$ slower welding linear speed compared to HPAW applications and the need for post-weld heat treatment in order to recover corrosion and toughness properties, decreases the welding efficiency of this process.

Intermetallic precipitates and $\gamma_{2}$ formation were observed in GMAW microstructure. The reason for formation of these phases is linked to multi-cycle thermal treatments during the process. The hardness values of GMAW specimens are higher than on specimens obtained by other welding methods. Despite its high hardness, impact energies show that weldment of GMAW was still ductile at $-50^{\circ} \mathrm{C}$. However, it has been reported that secondary phases cause sensitization and adversely affect corrosion properties.

Keyhole capability of PAW and HPAW techniques provided 
an opportunity of working with narrow-gap assemblies, and this led to complete the process in a single run for the thickness studied. Less total heat input and high aspect ratio of keyhole welds resulted in narrower HAZ and less residual stresses in the joints. However, excessive $\delta$ content in as-welded DSS was an adverse effect of autogenous PAW, like other keyhole welding processes without any additive. Whereas, during the keyhole based hybrid welding technique, HPAW, moderate cooling rates together with the advantage of addition of filler wire, consisting $4 \%$ excess $\mathrm{Ni}$, were consequently promoted sufficient amount of $\gamma$ in the microstructure of as-welded DSS. Additionally, the high-power density and synergic capability of the technique provided a narrower and higher toughness FZ and $\mathrm{HAZ}$ as compared to melt-in techniques with limited amount of detrimental intermetallic precipitation in as-welded DSS.

This study concludes that hybrid plasma gas-metal arc welding makes keyhole welding applicable for DSS and manufacturers can reduce lead times and provide better metallurgy for DSS assemblies for critical service in marine and industrial environments.

\section{References}

[1] NILSSON, J. Super duplex stainless steels, Materials Science and Technology, v.8, p.685-700, 1992.

[2] NILSSON, J.O.; WILSON, A. Influence of isothermal phase transformations on toughness and pitting corrosion of duplex stainless steel SAF 2507, Materials Science and Technology, v.9, p.545-554, 1993.

[3] KARLSSON, L.; RYEN, L.; PAK, S. Precipitation of intermetallic phases in $22 \% \mathrm{Cr}$ duplex stainless weld metals, Welding Journal, v.74, p.28-40, 1995.

[4] WESTIN, E.; FELLMAN, A. Effect of laser and laser hybrid welding on the corrosion performance of a lean duplex stainless steel, Journal of Laser Applications, v.22, n.4, p.150-158, 2010. [5] PEKKARINEN J.; KUJANPÄÄ, V. The effects of laser welding parameters on the microstructure of ferritic and duplex stainless steels welds, Physics Procedia, v.5, p.517-523, 2010.

[6] NILSSON, J.; KANGAS, P.; KARLSSON, T.; WILSON, A. Mechanical properties, microstructural stability and kinetics of $\sigma$ phase formation in $29 \mathrm{Cr}-6 \mathrm{Ni}-2 \mathrm{Mo}-0,38 \mathrm{~N}$ super duplex stainless steel, Metallurgical and Materials Transactions A, v.31, p.35-40, 2000.

[7] KORDATOS, J.; FOURLARIS, G.; PAPADIMITRIOU, G. The effect of cooling rate on the mechanical and corrosion properties of SAF 2205 (UNS 31803) duplex stainless steel welds, Scripta Metallurgica, v.44, p.401-408, 2001.

[8] MCPHERSON, N.; SAMSON, H.; BAKER T.; FERNANDEZ, S. Steel microstructures in autogenous laser welds, Journal of Laser Applications, v.15, p.200-211, 2000.

[9] KU, J.; HO, N.; TJONG, S. Properties of electron beam welded SAF 2205 duplex stainless steel, Journal of Materials Processing Technology, v.63, p.770-775, 1997.

[10] MCPHERSON, N.; CHI, K.; BAKER, T. Submerged arc welding of stainless steel and the challenge from the laser welding process, Journal of Materials Processing Technology, v.134, p.174-179, 2003.
[11] OMURA, T.; KUSHIDA, T.; KOMIZO, Y. Microstructural features and corrosion properties in laser welded duplex stainless steels, Welding International, v.14, p.257-260, 2000.

[12] CAPELlO, E.; CHIARELlO, P.; PREVITALI, B.; VEDANI, M. Laser welding and surface treatment of a $22 \mathrm{Cr}-5 \mathrm{Ni}-$ 3Mo duplex stainless steel, Materials Science and Engineering A, v.351, p.334-343, 2003.

[13] WU, H.; TSAY, L.; CHEN, C. Laser beam welding of 2205 duplex stainless steel with metal powder additions, The Iron and Steel Institute of Japan International, v.44, p.1720-1726, 2004.

[14] SATHIYA, P.; KUMAR MISHRA, M.; SHANMUGARAJAN, B. Effect of shielding gases on microstructure and mechanical properties of super austenitic stainless steel by hybrid welding, Materials and Design, v.33, p.203-212, 2012.

[15] DYKHNO, I.; DAVIS, R. Hybrid Welding: An Alternative to SAW, Welding Journal, v.86, n.10, p.42-47, 2007.

[16] YELBAY, H.I.; CAM, I.; GUR, C.H. Non-destructive determination of residual stress state in steel weldments by Magnetic Barkhausen Noise technique, NDT\&E International, v.43, p.29-33, 2010.

[17] MILLS, K.C.; KEENE, B.J.; BROOKS, R.F.; SHIRALI, A. Marangoni effects in welding, Philosophical Transactions of The Royal Society A, v.356, p.911-925, 1998.

[18] LU, S.; FUJII, H.; NOGI, K. Marangoni convection and gas tungsten arc weld shape variations on pure iron plates, The Iron and Steel Institute of Japan International, v.46, p.276-280, 2006. [19] DUPONT, J.; MARDER, A. Thermal Efficiency of Arc Welding Processes, Welding Journal, v.74, p.406-416, 1995.

[20] FUERSCHBACH, P.; KNOROVSKY, G. A Study of Melting Efficiency in Plasma Arc and Gas Tungsten Arc Welding, Welding Journal, v.70, p.287-297, 1991.

[21] SOUTHWICK, P.; HONEYCOMBE, R. Decomposition of ferrite to austenite in $26 \% \mathrm{Cr}-2 \% \mathrm{Ni}$ stainless steel, Metal Science, v.14, n.7, p.253-261, 1980.

[22] RAMIREZ, A.J.; LIPPOLD, J.C.; BRANDI, S.D. The relationship between chromium nitride and secondary austenite precipitation in duplex stainless steels, Metallurgical and Materials Transactions A, v.34A, p.1575-1597, 2003.

[23] KOKAWA, H.; TSORY, E.; NORTH, T.H. Nitride precipitation in duplex stainless steel weld metal, The Iron and Steel Institute of Japan International, v.35, n.10, p.1277-1283, 1995. [24] NILSSON, J.O.; KARLSSON, L.; ANDERSSON, J.O. Secondary austenite for mation and its relation to pitting corrosion in duplex stainless steel weld metal, Materials Science and Technology, v.11, n.3, p.276-238, 1995.

[25] CALLIARI, I.; ZANESCO, M.; BASSANI, P.; RAMOUS, E. The phase stability in $\mathrm{Cr}-\mathrm{Ni}$ and $\mathrm{Cr}-\mathrm{Mn}$ duplex stainless steels, Journal of Material Sciences, v.46, p.6916-6924, 2011. 